\title{
Prescriptive Committee Seats in Congress
}

\author{
Charles S. Bullock III, University of Georgia \\ David England, Arkansas State University
}

This research updates earlier work done on the phenomenon of prescriptive committee seats in the U.S. House of Representatives, and extends the investigation to the control of committee seats by state delegations in the U.S. Senate. The theoretical underpinning of the phenomenon also is updated to reflect the literature on congressional informal groups that has grown up since the phenomenon of state party delegation prescriptive committee seats first was identified. Here the incidence of the phenomenon is found to be strong and broadly similar in both houses during the period 1947-1988, although important interchamber differences were found to emerge along several dimensions.

Bullock (1971) and England and Bullock (1986) described the phenomenon of prescriptive committee seats (those under control of a state party delegation for an extended period) in the U.S. House. Our intention is to update those works in so far as they relate to the House and to extend the investigation to the control of committee seats by state delegations in the Senate.

Such an update and extension is warranted by the importance of informal groups in those bodies and by internal and external changes that have occurred that can affect the results of those previous studies.

The study of informal groups has not achieved the sway in legislative studies that studies of the motivations of individual members and the operations of formal groups have enjoyed (see, however, Brady and Bullock 1981 on the Conservative Coalition; Parker and Parker 1979 and 1985 on factions in House committees; Loomis 1981 on group caucuses; Evans 1986 on regional conflict). The state or state party delegation is even more neglected after some attention given earlier (e.g., Truman 1956; Fiellin 1962; Deckard 1972).

However, informal groups in general and state party delegations in particular can play significant roles in the legislative process as the previous work on prescriptive seats attests. In his initial work, Bullock (1971) stressed the role of state party delegation prescriptive seats as information conduits and contributors to policy and power biases. There are, however, even more reasons for attention to be given to that phenomenon.

First, on a structural level, the influence that state party delegations can bring to the policy process through their prescriptive seats can be a method of acknowledging the federal nature of our system of government. Second, if a member's presence on a committee is the way that most members are able to participate effectively in the policy process, prescriptive seats provide state party 
delegation members who are not on a particular committee an agent on that committee who can extend their policy influence. Moreover, prescriptive seats, by definition, can bring a degree of stability to committees faced with internal membership changes and fluctuating environmental demands. Thus, in the face of membership turnover, we could expect more stability in policy outputs, ceteris paribus, from a committee with a high percentage of prescriptive seats than one with a lower percentage.

In a related consideration, Hammond $(1990,61)$ speaks of the conflict management role that informal caucuses can play, and we would expect that the holders of prescriptive seats on a particular committee would constitute such an informal caucus on that committee as they are probably there for the same reason. Parker and Parker $(1985,20)$ amplify that point by their notion of the committee "core" which is the group of committee members most influential in the committee's decisions. We would expect that the holders of prescriptive seats on a committee would most likely constitute a significant part of the membership of that core since much effort has been expended by the state party delegations to maintain their presence on the committee.

Besides the theoretical concerns that motivate this work, internal and external changes argue for this reexamination of the existence of prescriptive seats over 21 congresses, more than a fifth of the institution's history. Smith and Deering $(1984,84)$ point out that prestige and constituency committees have grown in attractiveness. Increases in the number of committees and subcommittees from 263 in the 84th Congress to 310 in the 100th Congress (Stanley and Niemi 1988, 178), the creation of new standing committees and the abolishment of a few old ones, and an increase in the number of seats on standing committees all have affected the parameters of committee assignments.

Among the potentially more disruptive House changes was the reallocation of the assignment function from the Democratic members of the Ways and Means Committee to the Steering and Policy Committee, along with a greatly increased role for the Speaker ( however, see Copeland 1987 for an argument that the more things change the more they stay the same). Changes in House delegation size, such as New York's loss of 9 seats and Florida's gain of 11 since 1950, could affect the ability of House state party delegations to perpetuate committee holdings. Shrinking delegations would be expected to let their least desirable claims lapse while growing delegations could increase their portfolios by covering seats on lower priority committees. Reapportionment is not the only determinant of delegation size that could have an effect. Long-term changes in party fortunes also are a determinant of resources. Republican strength has burgeoned in Florida and Texas so that the GOP in those states has the potential to claim seats as its right where, when Bullock (1971) wrote, Tennessee was the only former Confederate state that could have met the standard for prescriptive right. While Massachusetts has lost representatives due to reapportionment, its Democrats may be better able to populate desired committees because only one Republican remained in 1988. 
In the Senate, victories by Republicans in all but two southern states may have disrupted patterns of committee control developed during generations of one-party politics.

Changes in norms also may have contributed to modifications in previous patterns of committee distributions. With the demise of apprenticeship (Asher 1973; Loomis 1988), junior members may be less docile and rebel at attempts to get them to hold down the delegation's claims for which they find no personal attraction. With the "greening" of Congress that started in the mid-1970s, when a youth movement began (Stanley and Niemi 1988, 165), there may have been a rise in egocentric members who placed self above delegation. Certainly, the decline in very senior members (Bullock 1972; Ornstein et al. 1984, 18-19) reduces the potential for prolonged seat occupancy by a single legislator. In the Senate, the Johnson Rule, which assured each Democrat one good committee before senior members got additional top appointments, would benefit competitive two-party states in which acquisition of seniority is more difficult. Finally, the general decline in norm adherence may have weakened claims that the same state was entitled to retain the committee seats it previously had staffed (on the general decline in norms see Ornstein et al.1984, 17-20).

In addition to changing norms and House reapportionment, changes in the national policy agenda may influence the desire of a delegation to continue its representation on a committee. The oil crisis, environmental concerns, labormanagement relations, civil rights, and the use of military force are but some of the issues that have fluctuated in salience since the end of World War II.

In sum, perhaps the most concise reason for the study of prescriptive seats is provided by Smith and Deering $(1984,241)$, who point out that the efforts of state party delegations to control committee seats are specifically recognized by members of the House Democratic Steering and Policy Committee, thirteen of whose members mentioned a state party delegation's claim as a criterion they consider in making committee assignments. Only the electoral needs of the members were mentioned more often than the same-state norm.

We study the incidence of long-term seat occupancy from 1947 (80th Congress) to 1988 (100th Congress). Bullock's (1971) original work covering the period 1947-1968 will serve as a baseline for House comparisons with a replication covering the period 1969-1988. Additionally, the ability to maintain prescriptive seats for the entire 42 year period will be examined. After a discussion of the standards used to identify prescriptive seats, the incidence of prescriptive seats in three time periods will be compared, conclusions concerning committee attractiveness drawn, comparisons between large and small partisan delegations and regions made, and policy implications discussed. In the Senate in place of delegation size, we explore variations in partisan control of committee seats regularly filled by a delegation. Our presentation will deal first with the House, then with the Senate. After separate analyses of each chamber, we will review interchamber similarities and differences. 


\section{Methodology}

Bullock (1971) focused on the behavior of state party delegations, and we follow that lead in analyzing House data. Since each state has but two senators, we look at the committee assignments of state delegations in the Senate. When appropriate, discussions of the Senate will reference the delegations, but persistent presence of one of a state's senators will suffice for prescriptive or extendedcontrol status, regardless of partisanship.

\section{Criteria for Assignment of Prescriptive Seats}

Bullock (1971) devised a three-part typology for methods of delegation control. Type I prescriptive seats had been held by the party delegation throughout the period studied by assigning successive members to a committee, and were the most convincing manifestation of delegation control since they required the most concerted use of resources over time. Continuous control by successive members is also our standard for a Type I seat. The original work defined a Type II prescriptive seat as multimember control for 20 of the 22 years studied. Here a Type II seat is one which a delegation has maintained for at least 36 of the 42 years. In the original study, Type III seats had been held by the same individual for 20 of the 22 years. For the 42 year period, a Type III seat is one held by a single member for 36 or more years. Consequently, it will be impossible to have established a prescriptive claim to seats in existence for less than thirty-six years.

\section{Criteria for Extended-Control Seats}

Comparisons of committee seats held by a delegation for at least all but two years of either 1947 to 1968 or 1969 to 1988 will permit an assessment of longitudinal changes. The criteria for the tripartite categorization of seats will be the same but adjusted for the shorter time-span. Seat control for either half of the post-war era will be referred to as extended control to distinguish it from prescription which requires that a seat be filled by a delegation for at least 36 of the 42 years. Long-term delegation presence on committees whose existence meets the standards for either half of the post-war years will be reported; however, short-lived committees such as Budget are excluded.

\section{The Incidence of Extended-Control and}

Prescriptive Seats

One important question is whether change in the internal and external environments of Congress has limited the ability of state party delegations to retain seats. A comparison between the incidence of extended-control seats for 1947 1968 with 1969-1988 presented in Table 1 throws light on that question. Despite 
change, continuity reigns. The total number of extended-control seats varied by only 3 (excluding Science and Technology) and the incidence of the types of seats in each period is similar. A comparison of the two periods shows a -13.8 percent differential in Type I seats, a +15.5 percent differential in Type II seats, and only $\mathrm{a}+1.9 \%$ differential in Type III holdings.

The increased number of seats filled with brief interruption may result from greater fluctuations in resources (number of members in a state party delegation) or less docile delegation members as a result of individuals' ambitions eclipsing delegation needs. The constancy in numbers and types of committee holdings suggests that interest in long-term committee presence is relatively fixed. If demand for a continued presence on committees was limited largely by availability of seats and personnel, then the number of seats held by a state party delegation since 1969 should exceed that for the earlier year since seats and average assignments per member have increased (Westefield, 1974; Ray and Smith, 1984).

The number of prescriptive seats for 1947-1988 (119) is almost 60 percent of the long-term seats for either half of the post-war period and represents a fifth of the average number of seats on committees that have functioned since 1947. If Type III occupancy, which must end with an incumbent's term, is excluded, then prescriptive seats equal more than three-fourths of the long-term seats for either half period. The continuity of so large a share of all House seats by state party delegations for so sizeable a portion of the history of the House vividly indicates the role of the same-state norm in the assignment process. Despite the seeming importance of the same-state norm, it is not always controlling and at times may be thwarted by the absence of a suitable claimant from the state experiencing a vacancy. Therefore, 75 percent of the prescriptive seats are Type II, while a plurality of the extended-control seats in either half period are Type I.

Reapportionment has not kept states from holding treasured seats. The two states that lost most heavily during the last two reapportionments -- New York lost 7 House seats (17.1 percent) and Pennsylvania lost 4 seats (14.8 percent) -nonetheless maintained prescriptive representation on relevant committees even though the number of prescriptive seats is 42.0 percent less than the number held in 1947-1968. New York only lost 4 committee seats (14.3 percent) or a rate of loss one-third that of the chamber. While Pennsylvania's rate of loss matched the chamber-wide figure, even that is an accomplishment in light of the Keystone State's drop in personnel. These states were judicious in accepting their losses, for the most part giving up slots on committees of relatively little utility to the delegation. Each state lost a seat on Judiciary, a committee whose popularity has declined to the point that its vacancies often exceed requests (Cooper 1979). Also given up were two seats on Interior and one each on Agriculture, House Administration, and Post Office. Pennsylvania, which is not known for its military bases -- 1986 defense expenditures there were par with Connecticut's (Barone and Ufijusa 1987) -- lost claims to two Armed Services seats.

By implication, changes in delegation sizes, in member interests, and in 


\section{Table 1. Incidence of Prescriptive Seats by Type and Committee}

\begin{tabular}{|c|c|c|c|c|c|c|c|c|c|c|c|c|c|c|c|c|c|c|c|}
\hline \multirow[b]{2}{*}{ Committee } & \multicolumn{4}{|c|}{$\begin{array}{c}\text { Prescriptive Seats } \\
1947-1968 \\
\end{array}$} & \multicolumn{4}{|c|}{$\begin{array}{c}\text { Prescriptive Seats } \\
1969-1988 \\
\end{array}$} & \multicolumn{4}{|c|}{ Change } & \multicolumn{4}{|c|}{$\begin{array}{c}\text { Prescriptive Seats } \\
1947.1988 \\
\end{array}$} & \multirow{2}{*}{$\begin{array}{c}\text { All } \\
\text { Prescriptive } \\
\text { Seats (\%) }\end{array}$} & \multirow{2}{*}{$\begin{array}{l}\text { Percent of } \\
\text { Seats By } \\
\text { Comm. Type (\%) }\end{array}$} & \multirow{2}{*}{$\begin{array}{l}\text { All } \\
\text { Committee } \\
\text { Seats }(\%)\end{array}$} \\
\hline & 1 & II & III & Total & I & II & III & Total & I & II I & III T & Total & I & II & III & Total & & & \\
\hline Prestize & 24 & 7 & 15 & 46 & 30 & 7 & 12 & 49 & +6 & 0 & -3 & +3 & 12 & 21 & 1 & 34 & 28.6 & 100.0 & 36.0 \\
\hline $\begin{array}{l}\text { Appro- } \\
\text { priations }\end{array}$ & 14 & 3 & 7 & 24 & 18 & 4 & 6 & 28 & +4 & +1 & -1 & +4 & 9 & 14 & 1 & 24 & 20.2 & 70.6 & 46.2 \\
\hline Rules & 1 & 2 & 4 & 7 & 2 & 0 & 3 & 5 & +1 & -2 & -1 & -2 & 1 & 0 & 0 & 1 & 0.8 & 2.9 & 7.2 \\
\hline $\begin{array}{l}\text { Ways and } \\
\text { Means }\end{array}$ & 9 & 2 & 4 & 15 & 10 & 3 & 3 & 16 & +1 & +1 & -1 & +1 & 2 & 7 & 0 & 9 & 7.6 & 26.5 & 31.4 \\
\hline Policy & 28 & 20 & 17 & 65 & 18 & 34 & 21 & 73 & -10 & +14 & +4 & +8 & 4 & 34 & 1 & 39 & 32.8 & $99.9^{*}$ & 19.0 \\
\hline Banking & 3 & 9 & 2 & 14 & 4 & 8 & 4 & 16 & +1 & -1 & +2 & +2 & 1 & 9 & 0 & 10 & 8.4 & 25.6 & 28.1 \\
\hline Commerce & 7 & 3 & 1 & 11 & 6 & 6 & 2 & 14 & -1 & +3 & +1 & +3 & 1 & 5 & 0 & 6 & 5.0 & 15.4 & 16.5 \\
\hline Education & 4 & 2 & 1 & 7 & 3 & 2 & 2 & 7 & -1 & 0 & +1 & 0 & 0 & 2 & 0 & 2 & 1.7 & 5.1 & 6.3 \\
\hline $\begin{array}{l}\text { Foreign } \\
\text { Affairs }\end{array}$ & 7 & 1 & 5 & 13 & 2 & 5 & 4 & 11 & -5 & +4 & -1 & -2 & 1 & 7 & 0 & 8 & 6.7 & 20.5 & 23.3 \\
\hline $\begin{array}{l}\text { Gove Op- } \\
\text { erations }\end{array}$ & 3 & 3 & 3 & 9 & 2 & 8 & 3 & 13 & -1 & +5 & 0 & +4 & 1 & 6 & 0 & 7 & 5.9 & 17.9 & 20.3 \\
\hline Judiciary & 4 & 2 & 5 & 11 & 1 & 5 & 6 & 12 & -3 & +3 & +1 & +1 & 0 & 5 & 1 & 6 & 5.0 & 15.4 & 18.3 \\
\hline
\end{tabular}




\begin{tabular}{|c|c|c|c|c|c|c|c|c|c|c|c|c|c|c|c|c|c|c|c|}
\hline$\frac{\text { Constit- }}{\text { uency }}$ & 37 & 23 & 13 & 73 & 30 & 26 & 18 & 74 & -9 & -1 & +4 & -6 & 11 & 29 & 0 & 40 & 33.6 & 100.0 & 19.1 \\
\hline $\begin{array}{l}\text { Agricul- } \\
\text { ture }\end{array}$ & 6 & 4 & 4 & 14 & 7 & 3 & 2 & 12 & +1 & -1 & -2 & -2 & 3 & 5 & 0 & 8 & 6.7 & 20.0 & 21.8 \\
\hline $\begin{array}{l}\text { Armed } \\
\text { Services }\end{array}$ & 9 & 5 & 5 & 19 & 6 & 2 & 7 & 15 & -3 & -3 & +2 & -4 & 4 & 5 & 0 & 9 & 7.6 & 22.5 & 22.5 \\
\hline Interior & 6 & 4 & 1 & 11 & 4 & 4 & 1 & 9 & -2 & 0 & 0 & -2 & 0 & 3 & 0 & 3 & 2.5 & 7.5 & 8.6 \\
\hline $\begin{array}{l}\text { Merchant } \\
\text { Marine }\end{array}$ & 9 & 3 & 0 & 12 & 6 & 5 & 1 & 12 & $-3+2$ & & +1 & 0 & 2 & 6 & 0 & 8 & 6.7 & 20.0 & 23.5 \\
\hline $\begin{array}{l}\text { Public } \\
\text { Works }\end{array}$ & 5 & 4 & 2 & 11 & 3 & 7 & 6 & 16 & -2 & +3 & +4 & +5 & 1 & 8 & 0 & 9 & 7.6 & 22.5 & 24.3 \\
\hline $\begin{array}{l}\text { Veterans' } \\
\text { Affairs }\end{array}$ & 2 & 3 & 1 & 6 & 2 & 1 & 0 & 3 & 0 & -2 & -1 & -3 & 1 & 2 & 0 & 3 & 2.5 & 7.5 & 11.0 \\
\hline $\begin{array}{c}\text { Science \& } \\
\text { Tech. }\end{array}$ & - & - & - & - & 2 & 4 & 1 & 7 & - & - & - & - & - & - & - & - & - & - & - \\
\hline Undesired & 5 & 8 & 8 & 21 & 5 & 4 & 4 & 13 & 0 & -4 & -4 & -8 & 1 & 5 & 0 & 6 & 5.0 & 100.0 & 8.3 \\
\hline D.C. & 3 & 2 & 3 & 8 & 1 & 0 & 1 & 2 & -2 & -2 & -2 & -6 & 0 & 1 & 0 & 1 & 0.8 & 16.7 & 4.6 \\
\hline $\begin{array}{l}\text { House } \\
\text { Admin. }\end{array}$ & 2 & 3 & 1 & 6 & 1 & 2 & 1 & 4 & -1 & -1 & 0 & -2 & 0 & 0 & 0 & 0 & 0.0 & 0.0 & 0 \\
\hline $\begin{array}{l}\text { Post } \\
\text { Office }\end{array}$ & 0 & 3 & 4 & 7 & 3 & 2 & 2 & 7 & +3 & -1 & -2 & 0 & 1 & 4 & 0 & 5 & 4.2 & 83.3 & 18.7 \\
\hline $\begin{array}{l}\text { Official } \\
\text { Conduct }\end{array}$ & - & - & - & - & 0 & 0 & 0 & 0 & - & - & - & - & - & - & - & - & - & - & 0 \\
\hline Totals & 94 & 58 & 53 & 205 & 83 & 71 & 55 & 209 & -13 & +9 & +1 & -3 & 28 & 89 & 2 & 119 & 100.0 & - & 20.4 \\
\hline
\end{tabular}

*indicates rounding error. 
Democratic assignment procedures have had no more than a modest impact on extended-control and prescriptive committee holdings. Continuity in committee attractiveness in the face of environmental changes, both internal and external, is the norm.

\section{Extended-Control and Prescriptive}

Seats by Committee

Table 1 shows approximately equal numbers of prescriptive seats on the three major types of committees. Since there are fewer prestige seats available, it is significant that the proportion of seats on these committees subject to protracted delegation control (36 percent) is almost twice as great as on policy or constituency committees (19 percent). Apparently delegations pay the greatest heed to maintaining their places on prestige committees. The large share of slots controlled on these committees is facilitated by their more widespread attractiveness to representatives, which eases the state party delegation's recruitment of replacements for vacancies. Almost one-fifth of the policy and constituency seats are held prescriptively while delegations least often maintain a continuous presence on undesired committees.

Appropriations has the most prescriptive seats with 24, followed by Banking (10), Ways and Means (9), Armed Services (9), Public Works (9), Foreign Affairs (8), Agriculture (8), and Merchant Marine (8). All committees except House Administration boast at least one prescriptive seat. The extraordinarily high numbers of prescriptive seats on Appropriations (a third of all Type I seats) is due to its large size and desirability. The same factors probably account for the consistent numbers of extended-control seats for the half periods in Table 1. When the period of study is divided at 1968, Appropriations had the most seats subject to extended delegation control in both periods. Ways and Means, Armed Services, and Banking also had large numbers of extended-control seats in the two periods. Notable changes over time were that additional seats on Appropriations, Public Works, Commerce, and Government Operations came under delegation control, while the number of long-term seats fell on Armed Services, Veterans' Affairs, and District of Columbia.

Two of the committees on which additional delegation claims developed in the second period became more desirable as arenas in which to pursue policy goals. Government Operations came to be appreciated for its encompassing oversight authority while Commerce's desirability rose as energy, the environment, health care, and consumerism became hot topics. In deference to one of these concerns, Commerce was rechristened as Energy and Commerce. Growth in extendedcontrol seats on these committees -- and on policy committees generally -- may be attributable to the heightened interest in policy making noted among freshmen in the early 1970s (Bullock 1976; Loomis 1988). The rise in delegation concern for Public Works, the one constituency committee marked by a growth in long- 
term occupancy, may stem from the ability to secure federal dollars for almost every district through that committee. Other constituency committees are useful to smaller numbers of legislators, e.g. those with military bases (Arnold 1979), large rural tracts, or a coastline, and most of these became less subject to the samestate norm. And while representatives may downplay party and policy in order to promote reelection (Fiorina 1978; Fiorina and Noll 1979), this has not led state party delegations to stake claims more frequently to constituency committee seats. One possibility is that long-term delegation control has suffered in the face of widespread competition for these vacancies. Alternatively, members have discovered that answering the mail, pursuing casework, and so forth can satisfy constituency expectations, thereby allowing the legislator to keep fences mended through means other than serving on a constituency committee. Yet another possibility emphasizes an environment in which self-interest increasingly dominates delegation interest. Fewer members may be willing to go to a constituency committee simply to keep a delegation's claim alive. Legislators whose own districts are affected little by a committee may spurn pleas to serve there even briefly.

Lest we overstress the decline in long-term service on constituency committees, the linkage remains important in some quarters. All of the delegations having seats on Merchant Marine and Fisheries are from coastal states or states adjoining the Great Lakes. Science and Technology positions belong to party delegations from states such as Texas, Florida, and California, whose stake in the subject matter of that committee cannot be denied.

Despite some fluctuations, the strongest trend is the maintenance of approximately equal numbers of extended-control seats on committees across the two periods. For eleven committees the number of those seats varied by less than three between the two half periods.

\section{Partisan Control}

Table 2 reports figures on partisan control by region and delegation size. Comparing the 1947-1968 period with the 1969-1988 period, the dominant pattern is high congruence in the maintenance of extended-control seats. The Democrats had 9.3 percent more extended-control seats in the latter period while the Republicans had 10.5 percent fewer. For the full period, the Democratic share of the prescriptive seats is somewhat larger than its average proportion of House membership (59.9 percent).

\section{Partisanship and Delegation Size}

Using an average delegation size of 10 to dichotomize, we find that smaller Democratic delegations controlled a majority of the extended-control seats in 1947-1968. Since 1969, that advantage disappears, and for the 42 years, the large 
Table 2. Partisan Control of Prescriptive Seats by Delegation Size and Region

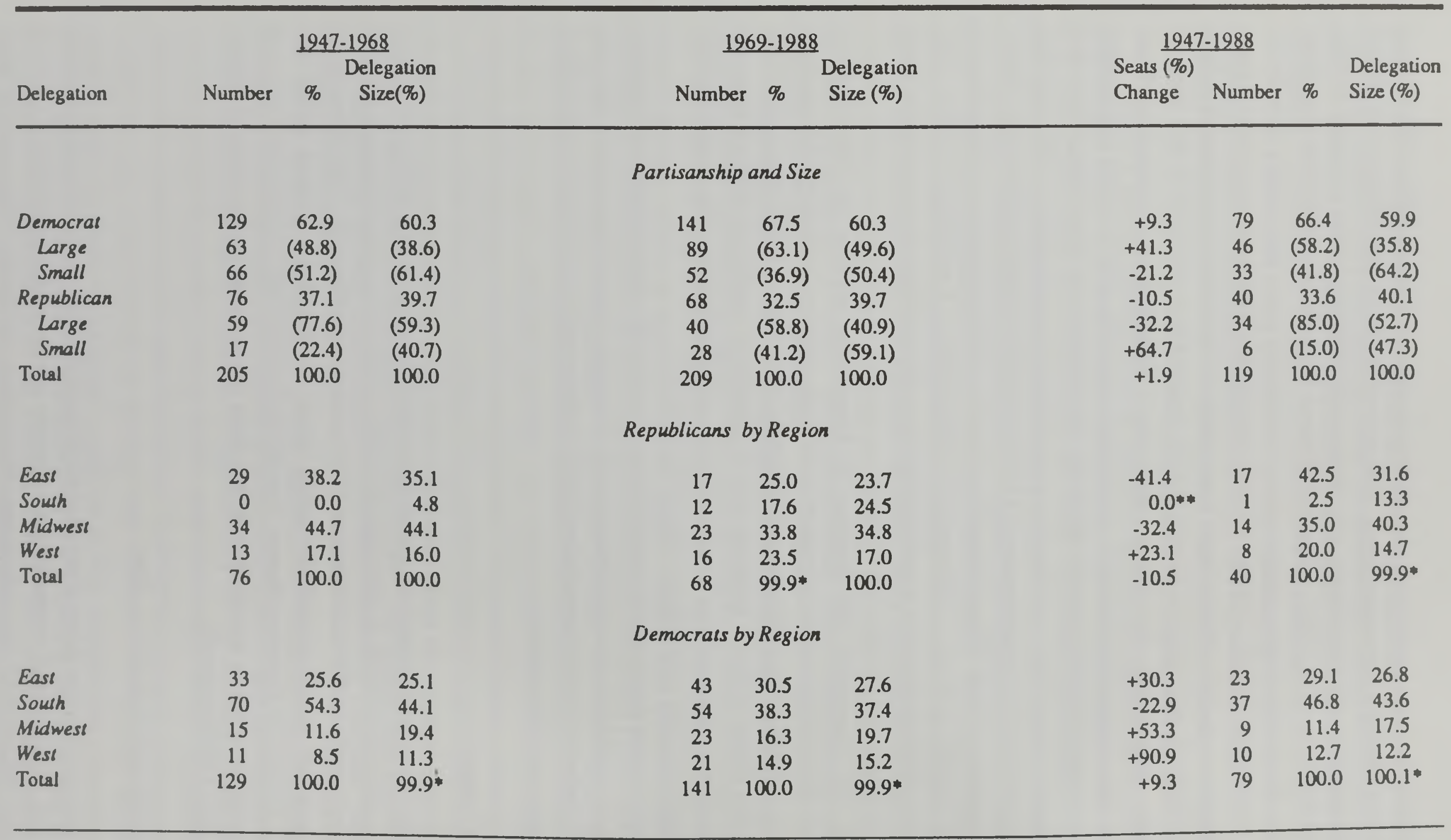

- Indicates rounding error.

* Cannot be computed.

Note: The criterion for a large delegation is an average of 10 members for the time period in question. Regions are as in Bullock (1971). 
delegations accounted for 58 percent of the party's prescriptive seats. The greater success of small delegations in the first two decades evaporated when they failed to convert Type III holdings with the passing of the incumbent. During the first period, approximately 60 percent of the claims of small Democratic delegations were Type III.

Two cases illustrate large Democratic delegations' advantage in prescriptive seats. For the 1947-1988 period, New York accounted for 9.0 percent of all House Democrats and controlled 16.5 percent of the Democratic prescriptive seats. Texas, with 8.5 percent of the Democratic membership, enjoyed 17.7 percent of the Democratic prescriptive seats.

Large delegation overrepresentation is even more pronounced among Republicans. New York Republicans made up 11.3 percent of the GOP membership in the 80th-100th Congresses, yet controlled 27.5 percent of the party's prescriptive seats. Large Republican delegations, while averaging 52.7 percent of the party members, control 85.0 percent of the prescriptive seats.

Size is such an advantage that three large state delegations have bipartisan representation through prescriptive seats on the Appropriations Committee and together control 10 of the 24 prescriptive seats on that committee. Both parties in at least one large delegation had prescriptive seats on eight standing committees in the House in 1988. California controls all of the prescriptive seats on Interior. In sum, large delegations from both parties control two-thirds of all prescriptive seats on Appropriations while accounting for 42.5 percent of the House membership.

Since small delegations lack the personnel to compete with the large delegations for extended-control and prescriptive seats, their best hope often is to concentrate on a single committee. Occasionally, even the smallest delegations can succeed. Republicans in one-person Alaska and Idaho delegations established extended-control Type II seats on Interior for the 1969-1988 period. Such singlemindedness is so rare that even if we look at the bipartisan efforts of one- and twoperson delegations, a Nevada seat on Interior would be the only additional prescriptive seat for a small delegation.

As in the original study (Bullock 1971), size counts. Larger delegations have more personnel so that even in the wake of electoral setbacks or the election of headstrong junior members, they can allocate resources to cover important committees. Smaller delegations experience more frequent interruptions in seniority, especially in the GOP, where weighted voting in the Committee on Committees further handicaps states with few Republicans in the House.

\section{Regional Distribution of Extended-Control}

and Prescriptive Seats

Of the 40 Republican prescriptive seats, delegations from the East are overrepresented while the South is underrepresented. ${ }^{1}$ As seen in Table 2, since 
the original study (Bullock 1971), the biggest change has involved the Midwest, which was represented proportionately in 1947-1968 with 44.7 percent of the region's extended-control seats but had only 33.8 percent of the extended-control seats in the second period (proportionality was maintained, however). This decline can be linked to the erosion of GOP strength in Illinois, Michigan, and Ohio.

The East's overrepresentation in Republican prescriptive seats is due to the two large states of New York and Pennsylvania, which hold 88.2 percent of that region's prescriptive seats. California, another large state, accounts for all of the prescriptive seats in the West. Three large midwestern states possess 78.6 percent of that region's prescriptive seats. Among Republicans, what appeared to be regional variations are really regional differences in the presence of large delegations.

Of particular interest on the Democratic side is the southern component. Table 2 shows that southern Democrats controlled 54 percent of the Democratic extended-control seats in the first period, when they accounted for 44.1 percent of all Democrats. For the 1969-1988 period, that percentage dropped to 38.3 percent, but for the entire 1947-1988 span, the figure was 46.8 percent, 7.5 points below their share of seats controlled from 1947-1969. With rising GOP strength in the South, that region's share of the Democrats' seats for 1969-1988 is in line with the average percent of southern Democrats in the House. Southern overrepresentation (3.2 points) in prescriptive seats is only slightly higher than eastern overrepresentation (2.3 points).

As in the initial study (Bullock 1971), midwestern Democrats continue to be underrepresented slightly. Western Democrats, like their eastern colleagues, have increased their share of their party's prescriptive seats. Despite the passing of the advantages enjoyed from 1947 to 1968 , the South remains the dominant region among Democratic prescriptive seat holders. Unlike Republicans, southern Democrats' prescriptive seats are dispersed with all but one delegation having at least one seat. Seemingly indicative of a regional strategy, southerners have at least one prescriptive seat on every standing committee except Interior and the undesired committees. Additionally, the region has been particularly successful on the prestige committees. Twelve of the region's 37 seats are in that category, and 57.1 percent of the southern Democratic delegations are represented on prestige committees.

There is little wasted effort in the form of overlap, i.e., duplicated effort at maintaining southern prescriptive seats, across the committees. An examination of the policy committees illustrates this point. Only when a particular state's own interests intrude is there duplication. For example, North Carolina has the region's seat on Foreign Affairs, Kentucky has that on Education and Labor, and Texas has that on Judiciary. In the case of Banking and Currency, Georgia and Texas, states with regional banking centers, have seats, but no other delegation does. Although not included in the figures above since it did not exist for the entire period, seats on Science and Technology are held by Texas and Florida -- in recognition of the 


\section{Houston and Kennedy Space Centers.}

Supporting what we take to be a regional strategy among the southern Democrats is evidence reported by Smith and Deering $(1984,241)$. Two members of the Steering and Policy Committee mentioned that regional considerations, especially southern, are important in making committee assignments. The role of the party delegation in a region might be more fully examined in the future.

\section{Senate}

The analysis of seat control in the Senate parallels that for the House with one exception. Since state delegations are limited to two members, to restrict prescriptive seats to instances in which the occupants share both state and party reduces the number to so few that analysis would be meaningless. Therefore, prescriptive Senate seats will be judged based on continuous occupancy by the same state regardless of party allegiance.

\section{Incidence of Extended-Control}

and Prescriptive Seats

Forty committee seats were held prescriptively by a state for at least 36 years from 1947 through 1988. Nine were held for the entire period, while another seven have been filled by the same state for 40 of the 42 years. These 40 seats constitute 19 percent of the average number of seats on the 13 committees that were in existence throughout the post-war period. ${ }^{2}$

As reported in Table 3, at least one seat on all 13 committees that existed throughout the post-war period meets the criteria for a Type I or II claim for the 42 years. These seats are found most commonly on Agriculture, Energy and Natural Resources (nee Interior), Appropriations and Armed Services, and these committees account for 60 percent of the prescriptive seats. These committees are valued because of the opportunities they provide to shower projects on the states of the legislators who are involved (Bullock 1985; Smith and Deering 1984). The dominant motivations for the first three are to promote reelection chances through constituency service, while both reelection and a concern for shaping public policy explain requests for Armed Services.

Table 3 also reports the extended-control and prescriptive shares of the mean number of committee seats held by states. More than 40 percent of the seats on Agriculture and Energy and Natural Resources (ENR) meet the standard for prescription, as do more than a quarter of the Armed Services and Labor seats. Approximately a fifth of the slots on Banking and Appropriations have prescriptive status through extended control by individual states. 
Table 3. Incidence of Prescriptive Committee Seats in the Senate

\begin{tabular}{|c|c|c|c|c|c|c|}
\hline & \multicolumn{2}{|c|}{$1947-1968$} & \multicolumn{2}{|c|}{$1969-1988$} & \multicolumn{2}{|c|}{$1947-1988$} \\
\hline & No. & $\%$ & No. & $\%$ & No. & $\%$ \\
\hline \multicolumn{7}{|l|}{ Reelection/Constituency } \\
\hline Agriculture & 8 & 53.3 & 12 & 75.0 & 7 & 45.2 \\
\hline Appropriations & 10 & 42.3 & 10 & 37.2 & 5 & 19.8 \\
\hline Commerce & 5 & 32.2 & 6 & 33.5 & 2 & 12.0 \\
\hline Energy \& Natural Resources & 9 & 58.6 & 8 & 46.2 & 7 & 43.0 \\
\hline Environment \& Public Works & 1 & 6.8 & 3 & 19.9 & 1 & 6.7 \\
\hline Post Office & 1 & 8.7 & - & - & - & - \\
\hline Veterans'Affairs & - & - & 4 & 38.8 & - & - \\
\hline \multicolumn{7}{|l|}{ Mixed Constituency-Policy } \\
\hline Armed Services & 4 & 25.9 & 8 & 46.0 & 5 & 30.5 \\
\hline Banking & 3 & 21.0 & 6 & 38.5 & 3 & 20.1 \\
\hline Finance & 3 & 19.0 & 3 & 16.1 & 1 & 5.9 \\
\hline \multicolumn{7}{|l|}{ Policy } \\
\hline Foreign Relations & 3 & 19.5 & 1 & 6.0 & 1 & 6.2 \\
\hline Government Affairs & 4 & 31.4 & 5 & 31.4 & 2 & 14.0 \\
\hline Judiciary & 2 & 13.8 & 4 & 24.5 & 1 & 6.5 \\
\hline Labor & 5 & 35.5 & 3 & 18.4 & 4 & 26.4 \\
\hline \multicolumn{7}{|l|}{ Undesired } \\
\hline Rules & 3 & 29.7 & 2 & 18.3 & 1 & 9.5 \\
\hline $\mathrm{N}$ & 61 & & 75 & & 40 & \\
\hline
\end{tabular}

Source: Smith and Deering $(1984,112)$. There have been two modifications. Veterans' Affairs is classified as a reelection constituency committee here while Smith and Deering judge it to be undesirable. This is based on Smith and Deering's report that the tw o requests for Veterans' Affairs in the 97 th Congress were based on constituency concerns. The Post Office Committee, having been abolished, is not in Smith and Deering's scheme, and is classified as Reelection/Constituency based on Bullock $(1985,797)$.

The first two columns of Table 3 identify 61 seats under extended delegation control from 1947-1969, including 27 that no longer are controlled by the state that then filled them. Through 1968 more than half of the seats on Agriculture and ENR were held by single delegations. On seven committees, extended-control seat holding was at least twice as frequent during the first period than prescriptive control for the entire period, with the differences being greatest on Appropriations, Commerce and Rules. Of 14 committees operating throughout 1947-1968, 30 percent of their seats were controlled by a single delegation.

In addition to seats filled by states for at least 36 years, another 35 seats were held by a state for 18 of the 20 years between 1969 and 1988, thereby achieving extended-control status. Thus, 75 seats $(32.5$ percent of the mean number of seats on 14 committees in existence since 1971) have experienced extended delegation control. At the upper extreme, in the second period 75 percent of the seats on Agriculture show signs of extended control, as do almost half of the seats on ENR and Armed Services. More than a third of the seats on Veterans' Affairs, Banking, Appropriations and Commerce have been filled by senators from the same states for two decades or more. In contrast, only one Foreign Relations seat seems to 
belong to a state since 1969 .

There is a finite number of seats that could be controlled by states if personal preferences were wholly subordinate to state interests. Certainly, that maximum has not been reached, but the number of seats likely to be held prescriptively may be fairly constant and substantially below the maximum. There was only a slight increase in extended-control seat holding from the first to the second time period. Due to committee expansions, 30 percent of the Senate seats were held by a delegation during the first half versus 32.5 percent in the second half of the postwar era. The two halves of the post-war period had similar numbers of Type III holdings ( 11 in the first half, 13 in the second). ${ }^{3}$ Of 61 seats that were potentially prescriptive in 1968,34 survived for two more decades, and six seats that were held for less than 20 of the first 22 post-war years have been held consistently for two more decades -- thereby raising them to prescriptive status. Of 36 seats with extended-control since at least 1971, 12 have not undergone a succession and 20 of them have been controlled by a delegation for no more than 20 years. Maintenance of only five seats extends back into the 1950s and two of these are Type III. It is reasonable, therefore, to expect that a number of slots currently held by states will not be converted into prescriptive seats.

\section{Extended-Control and Prescriptive Seats by Committee}

Inspection of the number of seats per committee in Table 3 reveals several patterns. First are committees on which extended control increased from the first period to the second. Included here are Agriculture (on which delegation seats rose from 8 to 12), Armed Services, and Banking. ${ }^{4}$ Linking these committees is their responsibility for items related to the economic well-being of a state. Senators seem to have become more interested in maintaining a presence on committees that have the potential to promote their own re-election by allowing them better opportunities for credit claiming.

Foreign Relations and Labor exhibit a second pattern, in which extendedcontrol committee seats declined. Foreign Relations consistently has been among the Senate's most popular committees (Matthews 1960; Bullock 1985; Smith and Deering 1984). High demand and a limited number of seats make it difficult for states to maintain a hold on Foreign Relations. Both Foreign Relations seats held during the first period but lost during the second were filled by a single senator and were given to new states when the incumbents left the chamber. A similar inability to convert Type III claims occurred with four Appropriations seats held prior to 1969, but since Appropriations is much larger than Foreign Relations, more states succeeded in maintaining an extended presence on the former. ${ }^{5}$ The decline on Labor may reflect a drop in the relevance of Labor's issues to the public and Congress. As the issues handled by this committee became less salient, interest in being on the committee has declined. 
A third pattern is a constant share of extended-control seats. Examples of constancy include Appropriations, Finance, Commerce, and Government Affairs. While all but the last of these are sought, at least in part, because of the opportunities for constituency service, the benefits are not limited to certain kinds of states as is the case for committees in which extended-control occupancy increased over time. Thus, while assignment to Agriculture is advantageous only if farming or ranching is a major economic component of a state, every state could benefit from having direct representation on Appropriations, Commerce, or Finance. ${ }^{6}$

Of the three types of seat holding, only John Stennis' position on Armed Services qualified as Type III for the full period and that now has ended. ${ }^{7}$ Given the limited number of players per state, it is not surprising that Type III occupancy is more than three times as common as Type I. Seats accorded the continuous Type I occupancy generally have been on constituency interest committees with three of the nine being on Agriculture and two more on ENR.

\section{Partisan Control}

With the spread of two-party competition, few states have not had at least one senator of each party during the last four decades. Consequently, maintenance of a longevity claim of ten requires the participation of members of both parties. Of 40 prescriptive seats, 24 have been shared by members of both parties. Table 4 shows that a dozen seats were held exclusively by Democrats, three times the number of GOP-only seats. The lower incidence of bipartisan seats in both half periods than for 1947-1988 suggests that a unipartisan approach can succeed for a while but becomes increasingly difficult.

Over the full 42 years, Democrats did better than Republicans because the former have been the majority party for three-fourths of the time. Moreover, when in the minority, the Democrats typically have comprised larger minorities: since World War II, there have not been fewer than 45 Democrats, whereas there have been as few as 32 Republicans and in seven congresses their numbers fell below 40.

Republicans' electoral disadvantages are underscored when the numbers of seats controlled by them in either half period are compared with the full period. From 1947-1968, the GOP stocked more seats (11 to the Democrats' 9), but only 3 were Type III while the Democrats' Type III holdings numbered 9 (figures for the half periods exclude prescriptive seats). However, their resources are too sparse to permit regular maintenance of seats; thus, a state must rely on Democratic help or lose its place. Bipartisan seats were fewer in the first period because there were more one-party states at that time.

Bipartisan participation in the creation of prescriptive seats since World War II has been most pronounced on reelection-constituency committees, where 17 of 22 seats have involved senators of both parties. For other committees, the 
incidence of bipartisan seats is more balanced. Bipartisan control, especially on Agriculture (7) and ENR (6) -- the premiere constituency-serving committees for certain types of states -- highlights the universal recognition that aid to farmers and management of federal land holdings can benefit legislators, regardless of their ideology or party affiliation.

Table 4. Partisan Control of Senate Seats Held for Extended Periods

\begin{tabular}{|c|c|c|c|c|c|c|c|c|c|}
\hline & \multicolumn{3}{|c|}{$1947-1968$} & \multicolumn{3}{|c|}{$1969-1988$} & \multicolumn{3}{|c|}{$1947-1988$} \\
\hline & Both & Dem & $\overline{\operatorname{Rep}}$ & $\overline{\text { Both }}$ & Dem & $\overline{\operatorname{Rep}}$ & $\overline{\text { Both }}$ & Dem & $\operatorname{Rep}$ \\
\hline \multicolumn{10}{|l|}{ Reelection/Constituency } \\
\hline Agriculture & 1 & 0 & 1 & 3 & 1 & 1 & 7 & 0 & 0 \\
\hline Appropriations & 0 & 1 & 4 & 2 & 3 & 0 & 2 & 3 & 0 \\
\hline Commerce & 0 & 3 & 0 & 1 & 3 & 0 & 1 & 0 & 1 \\
\hline $\begin{array}{l}\text { Energy and Natural } \\
\text { Resources }\end{array}$ & 2 & 1 & 0 & 0 & 0 & 1 & 6 & 1 & 0 \\
\hline $\begin{array}{l}\text { Environment and Public } \\
\text { Works }\end{array}$ & 0 & 0 & 0 & 1 & 1 & 0 & 1 & 0 & 0 \\
\hline Post Office & 1 & 0 & 0 & - & - & - & - & - & - \\
\hline Veterans' Affairs & - & - & - & 0 & 2 & 2 & - & - & - \\
\hline Sub-Total & (4) & (5) & (5) & (7) & (10) & (4) & (17) & (4) & (1) \\
\hline \multicolumn{10}{|l|}{ Mixed Constiluency-Policy } \\
\hline Armed Services & 0 & 0 & 0 & 1 & 0 & 2 & 3 & 2 & 0 \\
\hline Banking & 1 & 0 & 0 & 1 & 2 & 0 & 1 & 1 & 1 \\
\hline Finance & 0 & 1 & 1 & 0 & 0 & 1 & 0 & 0 & 1 \\
\hline Sub-total & (1) & (1) & (1) & $(2)$ & (2) & (3) & (4) & (3) & (2) \\
\hline \multicolumn{10}{|l|}{ Policy } \\
\hline Foreign Relations & 0 & 0 & 2 & 0 & 0 & 0 & 0 & 1 & 0 \\
\hline Government Affairs & 1 & 0 & 1 & 3 & 0 & 0 & 1 & 1 & 0 \\
\hline Judiciary & 1 & 1 & 0 & 0 & 2 & 1 & 1 & 0 & 0 \\
\hline Labor & 0 & 1 & 1 & 0 & 1 & 0 & 1 & 2 & 1 \\
\hline Sub-total & (2) & (2) & (4) & (3) & (3) & (1) & (3) & (4) & (1) \\
\hline \multicolumn{10}{|l|}{ Undesired } \\
\hline Rules & 0 & 1 & 1 & 0 & 1 & 0 & 0 & 1 & 0 \\
\hline $\mathrm{N}$ & 7 & 9 & 11 & 12 & 16 & 8 & 24 & 12 & 4 \\
\hline Type III & 0 & 8 & 3 & 0 & 9 & 3 & 0 & 1 & 0 \\
\hline
\end{tabular}

Number of Senators Participating in Building a Claim

Most of the prescriptive seats have passed through one or two successions. In addition to 15 seats that have been held by 2 senators and 14 that have had 3 
incumbents, 5 have been held by 4 senators, 2 by 5 and 3 by 6 . As one would expect, the committees that evoke efforts to maintain a state presence despite frequent personnel changes make policies with a significant impact on the interested state. These are the same committees most often filled by members of both parties. For example, three western states used a succession of five or more senators to maintain an ENR presence, while two southern and two midwestern states' Agriculture seats were occupied by at least four senators. Table 5 shows that prescriptive seats on Appropriations and Armed Services, which are almost as numerous as on Agriculture and ENR, have passed through fewer hands. The mean number of senators involved in maintaining a seat for the latter two committees is much greater than for the former two. The likely explanation for the difference is that the two more widely attractive committees cannot be passed on successfully through as many hands (compared with the narrower policy committees) because of greater competition for the former.

Table 5. Numbers of Senators Involved in Establishing

Prescriptive Seats, 1947-1988

\begin{tabular}{|c|c|c|c|c|c|c|}
\hline & $1-2$ & 3 & 4 & 5 & 6 & Avg. \\
\hline \multicolumn{7}{|l|}{ Reelection/Constituency } \\
\hline Agriculture & 2 & 1 & 1 & 1 & 2 & 4.0 \\
\hline Appropriations & 3 & 1 & 1 & 0 & 0 & 2.6 \\
\hline Commerce & 0 & 1 & 1 & 0 & 0 & 3.5 \\
\hline Energy \& Natural Resources & 1 & 3 & 1 & 1 & 1 & 3.7 \\
\hline Environment \& Public Works & 0 & 1 & 0 & 0 & 0 & 3 \\
\hline \multicolumn{7}{|l|}{ Mixed Constituency-Policy } \\
\hline Armed Services & 2 & 3 & 0 & 0 & 0 & 2.4 \\
\hline Banking & 1 & 1 & 1 & 0 & 0 & 3 \\
\hline Finance & 1 & 0 & 0 & 0 & 0 & 2 \\
\hline \multicolumn{7}{|l|}{ Policy } \\
\hline Foreign Relations & 1 & 0 & 0 & 0 & 0 & \\
\hline Government Affairs & 1 & 1 & 0 & 0 & 0 & 2.5 \\
\hline Judiciary & 1 & 0 & 0 & 0 & 0 & 2 \\
\hline Labor & 2 & 2 & 0 & 0 & 0 & 2.5 \\
\hline \multicolumn{7}{|l|}{ Undesired } \\
\hline Rules & 1 & 0 & 0 & 0 & 0 & 2 \\
\hline
\end{tabular}

If senators were distributed randomly across committees then there would be about a .2 probability of a freshman being assigned to a particular committee. ${ }^{8}$ To the extent that first-termers replace retiring senators when maintaining a state's seat, the likelihood that a committee would go through five successions by sheer chance is about .00032 . The greater the number of senators from a state who have served on a committee, the stronger the inference that continued service results 
from efforts to maintain a presence on the committee, and that these efforts may be advanced by a norm that accords the state the right-of-first-rejection when its seat is vacant.

Regional Distribution of Prescriptive Seats

The South, with its tradition of one-party politics and long tenure for incumbents, had 12 prescriptive seats, but so did the East, where bipartisan politics has a far longer history. Regions have different numbers of senators, so Table 6 includes the share of Senate seats for each region. ${ }^{9}$ The distribution of prescriptive seats is close to that of all senators, with the East slightly over-represented and the Midwest slightly underrepresented.

Table 6. Regional Distribution of Prescriptive Senate Seats, 1947-1988

(In percent)

\begin{tabular}{|c|c|c|c|c|c|}
\hline & East & Midwest & South & West & $\begin{array}{l}\text { No. of } \\
\text { Seats }\end{array}$ \\
\hline \multicolumn{6}{|l|}{ Reelection/Constituency } \\
\hline Agriculture & 14 & 43 & 43 & 0 & 7 \\
\hline Appropriations & 40 & 20 & 40 & 0 & 5 \\
\hline Commerce & 0 & 100 & 0 & 0 & 2 \\
\hline Energy and Natural Resources & 0 & 0 & 0 & 100 & 7 \\
\hline Environment and PublicWorks & 0 & 0 & 0 & 100 & 1 \\
\hline Sub-total & (14) & (27) & (23) & (36) & (22) \\
\hline \multicolumn{6}{|l|}{ Mixed Constituency-Policy } \\
\hline Armed Services & 20 & 0 & 80 & 0 & 5 \\
\hline Banking & 0 & 33 & 33 & 33 & 3 \\
\hline Finance & 100 & 0 & 0 & 0 & 1 \\
\hline Sub-total & (22) & (11) & (56) & (11) & (9) \\
\hline \multicolumn{6}{|l|}{ Policy } \\
\hline Foreign Relations & 100 & 0 & 0 & 0 & 1 \\
\hline Government Affairs & 50 & 0 & 50 & 0 & 2 \\
\hline Judiciary & 0 & 0 & 100 & 0 & 1 \\
\hline Labor & 100 & 0 & 0 & 0 & 4 \\
\hline Sub-total & $(75)$ & (0) & (25) & (0) & (8) \\
\hline \multicolumn{6}{|l|}{ Undecided } \\
\hline Rules & 100 & 0 & 0 & $(0)$ & (8) \\
\hline Total & 30 & 18 & 30 & 23 & 40 \\
\hline Senators & 25 & 23 & 29 & 23 & 96 \\
\hline
\end{tabular}

Regions display expected patterns of seat holding. Seven of nine western seats are on ENR. The South has four positions on Armed Services and three on 
Agriculture. Three of seven midwestern claims also are on Agriculture. The region with the greatest dispersion is the East, whose 12 seats are spread across eight committees with four seats on Labor.

The pattern for seats held continuously over the last two decades, but not sufficiently to qualify as prescriptive, has some similarities with Table 6 . The Midwest and South have multiple positions on Agriculture, and only the East has a seat on Labor. Looking toward possible future prescriptive seats, the West shows signs of developing claims on Appropriations, Armed Services, and Veterans' Affairs. The East has two seats on Public Works -- perhaps intended to help with the expense of redeveloping that region's aging infrastructure -- while the South has two seats each on Commerce and Government Affairs.

\section{Conclusions}

\section{Interchamber Similarities}

On several broad dimensions, the portraits for the two chambers are similar. In both houses approximately 20 percent of the committee seats were held by individual delegations for at least 36 of 42 years, with about 75 percent of those seats having experienced a brief break in control (Type II occupancy). To the extent that a seat consistently was held by members of one party, Democrats dominated with two-thirds of those positions. The same-state norm is relatively important and is a larger factor with the party that has been in the majority for most of the post-war years. It is impossible to determine whether the presence of more Democratic than Republican prescriptive seats results from different weight accorded this norm by the two parties or stems from greater ability of the larger group to allocate personnel to cover critical slots. In the Senate, where delegations are small, the most common format was for both parties to share in maintaining the state's claim.

\section{Interchamber Differences}

On several dimensions there are interchamber differences. There is no overlap for the four committees in each house that have the highest proportion of prescriptive seats. In the House, 46 percent of the Appropriations positions were held prescriptively, versus 20 percent in the Senate. The edge in prescriptive seats in the House over the Senate, on the committees most of ten peopled in this fashion, is: Ways and Means, 31 percent to 6 percent for Finance; Banking, 28 percent versus 20 percent; Public Works, 24 percent to 7 percent. From the Senate perspective, the most frequently held prescriptive seats outnumbered House holdings by the following margins: Agriculture, 45 percent to 22 percent; ENR, 43 percent to 9 percent; Armed Services, 30 percent to 23 percent; and Labor, 26 percent to 6 percent for Education and Labor. 
Multiple factors must be considered to account for these differences. The greater share of prescriptive seats on two House prestige committees than on their comparables in the Senate is probably due to the advantages that size of delegation conveys in the House. Larger state party delegations have extra muscle either through the weighted voting used by Republicans or by having multiple members on the Democratic Steering and Policy Committee. Further, large delegations more often have individuals who are available and popular and therefore can get support for their claims. In the Senate, where a vacancy on a committee -especially one as attractive as Appropriations or Finance -- coincides with the replacement of a senior member with a novice, a delegation may see its prescriptive claim rejected in deference to a popular, experienced competitor from another state. The disadvantage is more pronounced on Finance than Appropriations, because the latter is the largest in the body, now seating more than a quarter of the senators, or approximately half the Senate's state delegations.

With the most desirable committees not subject to the consistent hold of a few delegations (there also is only one prescriptive seat on Foreign Relations), extended control in the Senate is concentrated on committees where competition is less keen, i.e., committees that are particularly attractive to states with certain kinds of economic interests. Agriculture, ENR, and Armed Services are the leading examples.

\section{The Influence of Delegation Size and Region}

Size clearly was the driving force behind the frequency with which a state party delegation in the House upheld its claim to a committee. House delegations of the approximate size of state Senate delegations rarely controlled committee seats. That 19 percent of the Senate committee seats were held prescriptively indicates that once the advantage of large delegations is removed, it is quite feasible for small delegations to maintain a presence..$^{10}$

The major exception to the influence of delegation size in the House was the success of Southern Democrats. These legislators, who often have found themselves ideologically between their northern co-partisans and Republicans, have exercised the balance of power (Sinclair 1977). The mentality that prompted southerners to form a blocking coalition with Republicans (Brady and Bullock 1981) also seems to have led them to develop claims to a wide range of committees. These efforts were facilitated by the dominance of the Democratic party in the region for generations. Until Ways and Means Democrats lost the authority to make committee assignments in 1974, southern influence on that critical committee contributed to the region's overrepresentation and breadth of coverage among prescriptive holdings. During these years, southerners developed claims to seats on committees that now can be perpetuated through the same-state norm, even as the region becomes more competitive.

We have shown strong evidence of extended and prescriptive seat control 
and have indicated that the likelihood of this occurring by chance alone is low. Yet to be explored is the degree to which legislators voice prescriptive claims when pursuing their preferences. This paper in no way addresses the issue of the rate of success of same-state claims or of the ways in which such claims may vary by committee. An exploration of the extent and success of prescriptive claims also would include attention to the relative weight assigned such claims, both by those who articulate them and by those who receive them. Does the weight vary, depending on whether the claim is made by a novice seeking the seat of his/her predecessor or by a sitting senator wanting to transfer?

This paper covers the post-war period. Also yet to be explored is the degree to which a same-state norm operated in the prewar era. With the greater number of committees, it may have been more difficult for delegations to maintain a presence on committees. Also, as one moves back in time, turnover rates rise and average length of service declines (Polsby 1968). Shorter tenure increases the frequency with which a claim must be reasserted, and thus is jeopardized. Moreover, the period since 1955 has been remarkable for the prolonged hegemony of one party. Back when partisan control fluctuated, junior members of the party that was changing from majority to minority status sometimes were bumped from the most desirable committees as party ratios were adjusted. These expulsions would hinder the development of prescriptive claims.

\section{NOTES}

${ }^{1}$ States in each region are as follows: East: CT, DE, MA, ME, MD, NH, NJ, NY, PA, RI, VT, and WV; Midwest: IL, IN, IA, KY, MI, MN, NE, ND, OH, SD, and WI; South: AL, AR, FL, GA, KY, LA, MS, MO, NC, OK, SC, TN, TX, and VA; West: AK, AZ, CA, CO, HI, ID, MT, NV, NM, OR, VT, WA, and WY.

${ }^{2}$ Thirteen committees operated throughout the period studied; in addition, it was possible to have served on the Post Office and District of Columbia committees during the first half of the post-war era. These committees were abolished in the 1970 s while the Veterans' Affairs committee, created in 1971, was present long enough for senators to have met the 18 of 20 years standard for extended control during the second period. Small Business and Budget are too new to allow determination of whether states may be developing claims based on a continuous presence, and the Space committee's life did not coincide with either of our periods, although some states evinced seat control on that committee during its lifetime.

${ }^{3}$ This includes Stennis' Armed Services seat in the 1969-1988 set.

${ }^{4}$ The number of seats for a period equals the number held for only that period plus the number held throughout the 42 year period.

${ }^{5}$ The average number of Appropriations seats from 1947-1988 was just over 25, while on Foreign Relations the mean was slightly over 16.

${ }^{6}$ Arnold (1979) notes that, in the House, distributive benefits tend to go both to legislators serving on the relevant authorization committee and the Appropriations subcommittee dealing with a program. 
${ }^{7}$ The 101 st Congress is outside the purview of this paper, but in 1989 Stennis's Type III claim was converted when his successor, Trent Lott (R), joined Armed Services.

${ }^{8}$ This is not a precise probability, since for each individual senator the actual likelihood would be a product of the number and distribution of vacancies across committees at the time of assignment. A probability of about 2 reflects a senator assigned to three committees among 15 possible committees, assuming equal chances of assignment to each committee.

${ }^{9}$ Alaska and Hawaii are excluded from these figures, since they have not been states long enough for their senators to have established a prescriptive claim under the definition used here.

${ }^{10}$ Since senators hold more assignments than House members, it is somewhat misleading to compare the success of a Senate delegation with that of one-or-two-member House delegations. A more appropriate comparison for the Senate might be a three-person House delegation. Three-member state party delegations in the House rarely have prescriptive claims.

\section{REFERENCES}

Arnold, R. Douglas. 1979. Congress and the Bureaucracy: A Theory of Influence. New Haven: Yale University.

Asher, Herbert B. 1973. The Learning of Legislative Norms. American Political Science Review 67 (June): 499-513.

Barone, Michael, and Grant Ufijusa. 1987. The Almanac of American Politics, 1988. Washington, DC: National Journal.

Brady, David W., and Charles S. Bullock, III. 1981. Coalition Politics in the House of Representatives. In Lawrence C. Dodd and Bruce I. Oppenheimer, eds., Congress Reconsidered, 2nd ed. Washington, DC: Congressional Quarterly Press.

Bullock, Charles S., III. 1971. The Influence of State Party Delegations on House Committee Assignments. Midwest Journal of Political Science 15: 525-546.

1972. House Careerists: Changing Patterns of Longevity and Attrition. American Political Science Review 66: 1295-1300.

. 1976. Motivations for U.S. Congressional Committee Preferences: Freshmen of the 92nd Congress. Legislative Studies Quarterly 1: 201-212.

. 1985. U.S. Senate Committee Assignments: Preferences, Motivations, and Success. American Journal of Political Science 29: 789-808.

Cooper, Ann. 1979. Budget is In, Ethics Out in Congressional Shopping for Committee Assignments. Congressional Quarterly Weekly Report 37: 155-156.

Copeland, Gary W. 1987. Seniority and Committee Transfers: Career Planning in the Contemporary House of Representatives. Journal of Politics 49: 553-564.

Deckard, Barbara. 1972. State Party Delegations in the U.S. House of Representatives. Journal of Politics 34: 199-222.

England, David E., and Charles S. Bullock, III. 1986. Prescriptive Seats Revisited. American Journal of Political Science 30: 496-502.

Evans, Diana Yiannakis. 1986. Sunbelt versus Frostbelt: The Evolution of Regional Conflict over Federal Aid to Cities in the House of Representatives. Social Science Quarterly 67: 108-117. 
Fenno, Richard F. 1973. Congressmen in Committee. Boston: Little Brown.

Fiellin, Alan. 1962. Functions of Informal Groups in Legislative Institutions: A Case Study. Journal of Politics 24: 72-91.

Fiorina, Morris P. 1978. Congress: Keystone of the Washington Establishment. New Haven: Yale University.

and Roger G. Noll. 1979. Majority Rule Models and Legislative Elections. Journal of Politics 41: 1081-1104.

Hammond, Susan W. 1990. Committee and Informal Leaders in the U.S. House of Representatives. In J.J. Kornacki, ed. Leading Congress: New Styles, New Strategies. Washington, DC: Congressional Quarterly Press.

Kingdon, John W. 1981. Congressmen's Voting Decisions, 2nd ed. New York: Harper and Row.

Loomis, Burdett A. 1981. Congressional Caucuses and the Politics of Representation. In Lawrence C. Dodd and Bruce I. Oppenheimer, eds., Congress Reconsidered, 2nd ed. Washington DC: Congressional Quarterly Press. . 1988. The New American Politician. New York: Basic Books.

Matthews, Donald R. 1960. U.S. Senators and Their World. New York: Vintage.

Ornstein, Norman J., Thomas E. Mann, Michael J. Malbin, Allen Schick, and John F. Bibby. 1984. Vital Statistics on Congress, 1984-1985. Washington, DC: American Enterprise Institute.

Parker, Glenn R. and Suzanne L. Parker. 1985. Factions in House Committees. Knoxville: University of Tennessee Press.

Polsby, Nelson W. 1968. The Institutionalization of the U.S. House of Representatives. American Political Science Review 62: 1144-168.

Ray, Bruce A. and Steven S. Smith. 1984. Committee Size in the U.S. Congress. Legislative Studies Quarterly 9: 679-695.

Sinclair, Barbara Deckard. 1977. Who Wins in the House of Representative: The Effect of Declining Party Cohesion on Policy Outputs, 1959-1970. Social Science Quarterly 58: 121-128.

Smith, Steven S. and Christopher J. Deering. 1984. Committees in Congress. Washington, DC: Congressional Quarterly Press.

Stanley, Harold W. and Richard G. Niemi. 1988. Vital Statistics on American Politics. Washington, DC: Congressional Quarterly Press.

Truman, David B. 1956. The State Delegation and the Representatives. American Political Science Review 50: 1023-1045.

Westefield, Louis P. 1974. Majority Party Leadership and the Committee System in the House of Representatives. American Political Science Review 68: 1593-1604. 